\title{
The orientation and mobility of visual impaired people in bus and subway networks in Brazil
}

\author{
Orientação e mobilidade de usuários com deficiência \\ visual em sistemas de transporte por ônibus e metrô no \\ Brasil
}

\begin{abstract}
Carolina Stolf Silveira
Marta Dischinger
Abstract

$\mathbf{S}$

patial orientation depends both on the information available in the surrounding's environment and on the individual's ability to perceive and deal with this information. To be fully understand by its users as a transport network and, to independently move from one place to another, the urban public transport service must be able to provide accessible information where users can easily discover and reach different, and to socially engage in local activities. In Brazil, the information disposable to users is scarce and sometimes nonexistent in the urban public transport (PT), especially regarding the supply of information to everyone. This paper presents some doctoral research's results applied in Brazil and discuss blind users' orientation and mobility in urban public transport network. The investigation involved around two hundred blind and partially impaired users from many Brazilian regions where surveys were conducted; additionally, interviews with a focus group and the "Accompanied Walks" method. The results of the latter are here presented, showing environmental barriers and users needs.

Keywords: Orientation. Mobility. Blind users. Urban public transport.

\section{Resumo}

Orientação espacial depende tanto da informação contida no ambiente quanto da capacidade do indivíduo em perceber e lidar com essa informação. Para poder entender um sistema de transporte público urbano e mover-se de forma

${ }^{1}$ Carolina Stolf Silveira

${ }^{1}$ Universidade Federal de Santa

Catarina

J oinville - SC - Brasil

${ }^{2}$ Marta Dischinger ${ }^{2}$ Universidade Federal de Santa

Catarina
Florianópolis - SC - Brasil

Recebido em 05/11/17

independente de um lugar para outro, esse serviço deve fornecer informações acessíveis aos usuários, para que esses possam exercer seu direito de ir e vir, bem como chegar aos lugares e atividades. No Brasil, a informação disponível para os usuários é escassa e às vezes inexistente, especialmente no que se refere ao fornecimento de informações não visuais. Este artigo apresenta alguns dos resultados de uma pesquisa de doutorado que ouviu cerca de duzentas pessoas de Norte à Sul do país. Dentre os métodos aplicados, os resultados dos Passeios Acompanhados são apresentados neste artigo, buscando refletir acerca da orientação e mobilidade de usuários com cegueira e baixa visão em seus deslocamentos urbanos utilizando um sistema de transporte coletivo.
\end{abstract}

Aceito em 13/06/18
Palavras-chave: Orientação. Mobilidade. Usuários com cegueira. Transporte público.

SILVEIRA, C. S.; DISCHINGER, M. The orientation and mobility of visual impaired people in bus and subway networks in 195 Brazil. Ambiente Construído, Porto Alegre, v. 19, n. 1, p. 195-208, jan./mar. 2019.

ISSN 1678-8621 Associação Nacional de Tecnologia do Ambiente Construído.

http:/ / dx. doi. org/ 10.1590/ s1678-86212019000100301 


\section{Introduction}

Since` 2015 the author, a Ph.D. student of the Federal University of Santa Catarina, has been researching and addressing the state-of-the-art knowledge on the following topics:

(a) the user's perception and their spatial orientation in PT networks;

(b) the available information systems in different PT networks; and

(c) the orientation techniques and 'assistive technologies', and its literature.

The research involved more than two hundred blind and partially sighted people from many cities across Brazil. Digital surveys were applied containing 26 questions about the use of tactile floors which 70 persons answered; 53 testimonials about the idealized wayfinding system for PT users were collected; discuss with 78 blind and low vison people were made through a focus group called "Accessibility and Transport" which participants exchange good and bad experiences using PT, and their ideal scenario; and, lastly, 05 applications of the "Accompanied Walk" method (DISCHINGER, 2000) were administrated.

This article is focused on present the main results of the "Accompanied Walks", which are obtained from the blind participants' perceptions about the public transport system of three Brazilian cities: Joinville, São Paulo, and Florianópolis.

\section{Contextualization}

Activities available in urban public spaces constitute centers that generate population movement (centers of interest), whether for work, study, leisure, or other personal and/or collective activities. This means it is often necessary to move from one place to another using public transport, in order to guarantee freedom of movement to all citizens, as set out in the Brazilian Federal Constitution of 1988.

The Brazilian National Public Transport Association (ANTP, in Portuguese) classifies transport in two: individual or mass and private or public. The research looked at mass public modes of transport - those that allow the general public simultaneous access to transport, normally via a pay scheme that is subject to some form of government regulation such as trains, the subway, or buses - the last of which is the most common in Brazil. Public mass transport is an essential service for the entire population and is directly related to walking.

One of the principles of the United Nations Convention on Disabled Rights is Equal
Opportunities. This principle establishes that society - including the physical and cultural elements, housing and transport, welfare and healthcare, education and employment, cultural and social life, and sports and leisure - should be accessible to all.

Meeting these needs means reaching access requirements, which presuppose access to and utilization of a range of locations and activities. One of the prerequisites for providing access to mass public transport is to give passengers the information needed to help guide them through the physical-spatial elements of mass public transport: routes to and from, between boarding points, the boarding points themselves, and the vehicles.

Information should be considered one of the major factors of service provision, and the reason why is because it is fundamental to guarantee universal access to public transport, as well as enables passengers to find and reach locations and to engage in local activities. Moreover, information is a crucial mean to support independent and safe navigation for blind and visual impaired passengers while in the vehicles or ensuring their rights.

The level of difficult in acquiring information about the service can be an impediment for many users. In addition, high level of available information might hold loyal fares as they will fell more confident to navigate thought the system while the level of trust in the system increases. At the same time, commuters will have more control over their movements. It is being shown for some time the influence of the availability of accessible and efficient information in increasing the number of passengers while reducing the preference for private motorised vehicles. As a consequence, issues as congestion, environment degradation, pollution and accident rates are mitigated. It is clear that the prioritisation of public transport services, as well the availability of good service information plays an indispensable role in reducing mobility problems in cities.

The Brazilian National Policy on Urban Planning, set by the National Law n. 12,587 in 2012 (BRASIL, 2012), establishes in its Chapter III the citizen's rights on transportation. Article 14 go further clearly states that users are entitled to "having free-of-charge, accessible information on boarding and departure points, itineraries, schedules, service charges, and modes of interaction with other systems"; in addition to "having a safe and accessible environment to use the National Urban Mobility System”. 
In spite of this, information available to users in the Brazilian urban public transport is inadequate, and in many times non-existent, especially regarding the supply of user-friendly information to all commuters. Mostly, when some information is provided, it is only written and (badly) graphically displayed, discriminating groups as the visually impaired or illiterate.

Information about the public transport network can easily be provided through visual maps, audible warnings, vehicle colour, and bulletin boards at bus stops, on buses, and at stations, which will be only fully read by the so-called 'standard user' - those who are literate and can use all their perceptive senses, ignoring the whole range of travellers with some disability. As example, how any with some extent of visual impairment can access the same information offered and navigate through the complexity of the spatial understanding of the transport network? Summarising, it is important to question how information design can ease the difficulties faced by others than the 'standard users'?

Dischinger (2000) debates the significance of the perceptive processes in the cognition of urban spaces for the visually impaired, and concluded that studies on the evaluation of spatial accessibility for this group should include studies on permanent and dynamic references related to identification, exploration, and independently decision-making, in addition to traditional attributes analysis.

In order to understand the distinctive means of procurement intelligence on spatial organisation, James Gibson introduced in 1966 the 'Theory of Sense Perception. The theory is a basic reference with prolong implications on the exploration of the methods of observation of surrounding spaces, and explaining the functions between senses. Gibson's theory is classified as a basic orienting; auditory; haptic; taste-smell; and visual systems analysis.

The first, basic orienting, is responsible for the body balance and main basic directions of up and down related to the planes of the ground. The second, auditory system, responds to the vibrations of the air and to the specific inputs the nature of the original vibratory events. The third, haptic system, is sensible for the perception of passive and active touch (object shapes, material states, solidity of viscosity), for temperature distinction, and for distinction of ones owns movements. The fourth, taste-smell system, is the use of nose and mouth joint to obtain information about food, which combined with the fifth, the haptic system, allow us to feel the consistency, the texture and the temperature of the aliments.
Lastly, the visual system, that instantly and simultaneously can register, form, depth and distance. This particular system, also controls the movements of objects and individuals in space and in the spatial layout of the environment. It is the only perceptual system that detects variables of colour, and transformations in light. According to Okamoto (2002), vision alone accounts for $87 \%$ of human perceptive activities, in a way that is understood as the most conscious sense for those who can see. For those who cannot, this means that the other perceptual channels gain substantiation during the orientation and mobility processes.

Considering all that challenges faced by visually impaired people, this author's doctoral research was focused in explore orientation strategies for this particular group while using public transport networks, encompassing its peculiarities and urban references to supports for the creation and development of accessible information system. Hence, a comprehensive, accessible and userfriendly information system can effectively allow a broad understanding of the urban spatial surroundings. Furthermore, it is feasible that the research findings aid other groups - such as illiterate, elderly and people with cognitive impairment - to navigate across public transport networks.

The investigation looks at which spatial elements are capable of being perceived and recognized by blind and visually impaired, acknowledging they what, when, where, and how often information is necessary. Likewise, what kind of support is most appropriate for each case. Furthermore, the study characterises:

(a) the provided information about the place and environment they are in (static information);

(b) the itinerary and time duration in the appropriated space and time;

(c) how the information should be displayed/given; and

(d) what kind of details about locations and waiting-time (dynamic information) ought be presented.

An ideal information system, is expected to be tailored, use physical and tactile and digital maps, audio resources (including audio-description), tactile elements (maps, floors, panels), remoted digital information, and other tools which can offer that need information at the right to time to those who need it.

Additionally, the research follows the general recommendations for spatial accessibility (Universal Design) defined by the author in her 
master dissertation, chapter 4, as a criterion for each activity in the main elements of the Brazilian public mass transport system. Architecture and spatial planning teaching and research in Brazil is far from including the subject of visually impaired travellers in public transport systems. A lack of studies on orientation strategies is noticeable, especially when reflecting behaviours of information perception, and the use of assistive technologies which empowers disadvantage commuter groups. This research aims to fill this lacuna.

\section{Methodology}

The methodology opted in this research is qualitative and descriptive, as subjective information it which defines reality levels cannot be quantified. The exploration included behaviors analysis and the opinions of blind and visually impaired public transport users of different Brazilian cities, such as São Paulo, Rio de Janeiro, Recife, Florianópolis, Joinville e Curitiba.

Accompanied Walk, developed by Dischinger, was one of the methods applied. The method objects the conventional environments visual analysis as the blind would not be able to identify positive spatial references through interviews or descriptions. So, rather than visually portray its ambiances, the 'Accompanied Walks' occur in a predefined route, when the subject preforms autonomously its path, stating its perceptions to the research, who will record it and photograph relevant points.

In addition, the researcher understand that more data collection was needed. Not only the environment perception during the 'Accompanied Walk' was inquired, but also later, when the 'accompanied' were using any type of public transport. Bell et al. (1978) clearly express the need of measuring the moods, thoughts, attitudes, and behaviours; asking those interviewed how they feel, what they think, and what they do or have done differently. Herssens (2011, p. 308) adds, saying that " $[. .$.$] the cooperation with blind people turned$ out to be very valuable [...] can offer opportunities for researchers to learn more about multi-sensory experiences.”.

\section{The accompanied walks}

Five 'Accompanied Walks' were made thought this research, being one with a partially sighted and four with blindness. However, only three will be detailed in this article. From the three walks, two subjects used a white cane and one a guide dog. The commuting walk in Joinville and Florianópolis were made by buses while in São Paulo by subway. Sidewalks analyses were made as it were part of the journey - from the point of origin to the point of destination.

Thus, before starting describing the walks, the following table provides some details about the cities' and interviewers' profiles (Table 1).

\section{J oinville}

The first Accompanied Walk was applied in Joinville, the largest city of Santa Catarina State South of Brazil, with 583,144 inhabitants (INSTITUTO..., 2018), and the author's hometown. The only public transport available in the city is by bus. The city's public transport network has 10 bus stations, and 365 available vehicles. According with the data from the Origin and Destination Survey, $25 \%$ of all daily trips are made by public transport, $23 \%$ by walking, $11 \%$ by cycling and $41 \%$ by cars/motorcycles.

Table 1 - Interviewers' profiles

\begin{tabular}{|l|l|l|l|l|l|}
\hline City & $\begin{array}{l}\text { Transport } \\
\text { System }\end{array}$ & \multicolumn{1}{|c|}{ Interviewee's Profile } & $\begin{array}{l}\text { Orientation and } \\
\text { Mobility } \\
\text { Techniques }\end{array}$ & Reason & Frequency \\
\hline Joinville & $\begin{array}{l}\text { sidewalks }+ \\
\text { bus + bus } \\
\text { station }\end{array}$ & $\begin{array}{l}\text { congenial blind woman, 36 } \\
\text { years old, guide dog }\end{array}$ & $\begin{array}{l}\text { yes, since she was } \\
\text { a child }\end{array}$ & $\begin{array}{l}\text { work - } \\
\text { home }\end{array}$ & every week day \\
\hline São Paulo & $\begin{array}{l}\text { station }+ \\
\text { subway }+ \\
\text { sidewalks }\end{array}$ & $\begin{array}{l}\text { congenial blind woman, } 40 \\
\text { years old, cane user }\end{array}$ & $\begin{array}{l}\text { yes, since she was } \\
\text { a child }\end{array}$ & pleasure & $\begin{array}{l}\text { but know the subway } \\
\text { system and the } \\
\text { Paulista Avenue }\end{array}$ \\
\hline Florianópolis & $\begin{array}{l}\text { bus station }+ \\
\text { sidewalks }\end{array}$ & $\begin{array}{l}\text { blind man (acquired when } \\
\text { he was 20), 46 years old, } \\
\text { cane user }\end{array}$ & $\begin{array}{l}\text { yes, since he } \\
\text { became blind }\end{array}$ & pleasure & every week day \\
\hline
\end{tabular}


The primary interviewee is a 36-years-old blind (congenital blindness) woman, and support secretary at the City Hall, graduated in secondary school. The tour began at her workplace and the destination was her residence. This is the journey she makes five days per week.

The participant left the building escorted by her guide dog (Figure 1a) heading to the bus stop (Figure 1c). In order to reach the bus stop, she had to cross the street, however she was not able to autonomously accomplish the task as the pedestrian traffic light in place offers no sound warning. So, a third party (sighted person) had to help her to cross (Figure 1b). It was observed that the dog took her near the pedestrian crossing, but not exactly on it. Though, the participant later commented that the dog is still on training.

Arriving at the bus stop, she perceived the arrival of the vehicle by its sound when it was very close. As she take the same bus daily and the bus driver knows her, the driver made the stop at the right time (Figure 2a).

While the participant was boarding the vehicle with her dog, she easily finds a preferred seat behind the drive (Figure 2b) and inform the driver her destination, the supermarket which is on her way home. At this moment, the contributor clarifies that without others help - in this case the driver - she would not know where she was supposedly to disembark. After disembarking, the heads to the supermarket to buy groceries; once again, a third party was needed to help her (all the purchasing were made with a supermarket employee's and accompanied by her dog).

After she did the supermarket, she returned to the same bus stop and asked the researcher to signal the driver to board when her line is arriving. The researcher asked how she does if there is no one in the bus stop, she responds that she has to stop all the buses which she listens to arrive.

\section{Figure 1 - The participant left her work place guided by a coworker and wait for the bus}
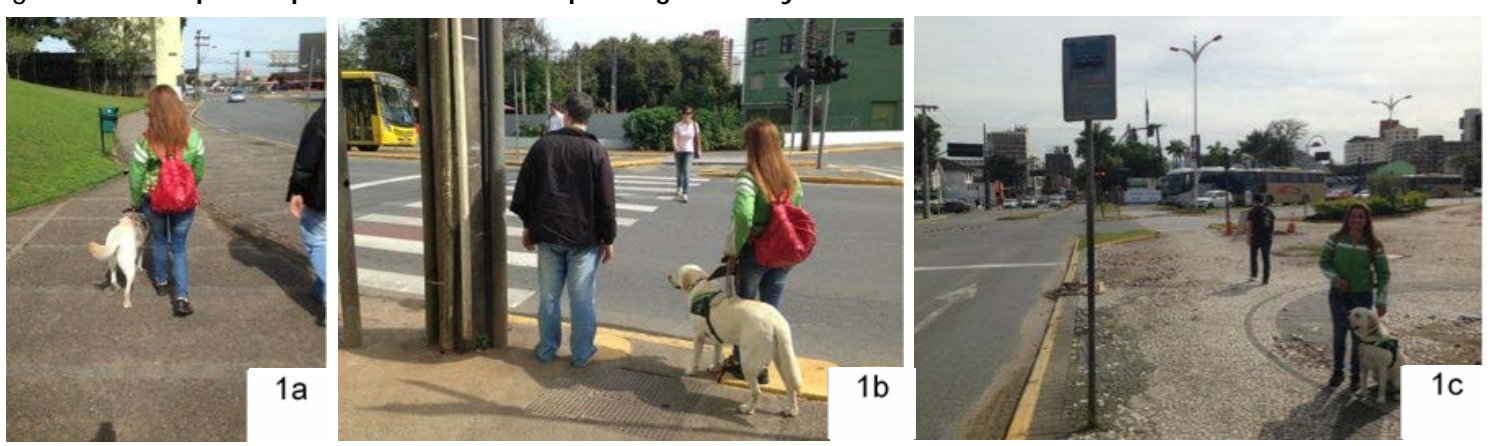

Source: Researcher's Photographic Collection (2015).

Figure 2 - The participant boarding on the bus and left it to go the supermarket
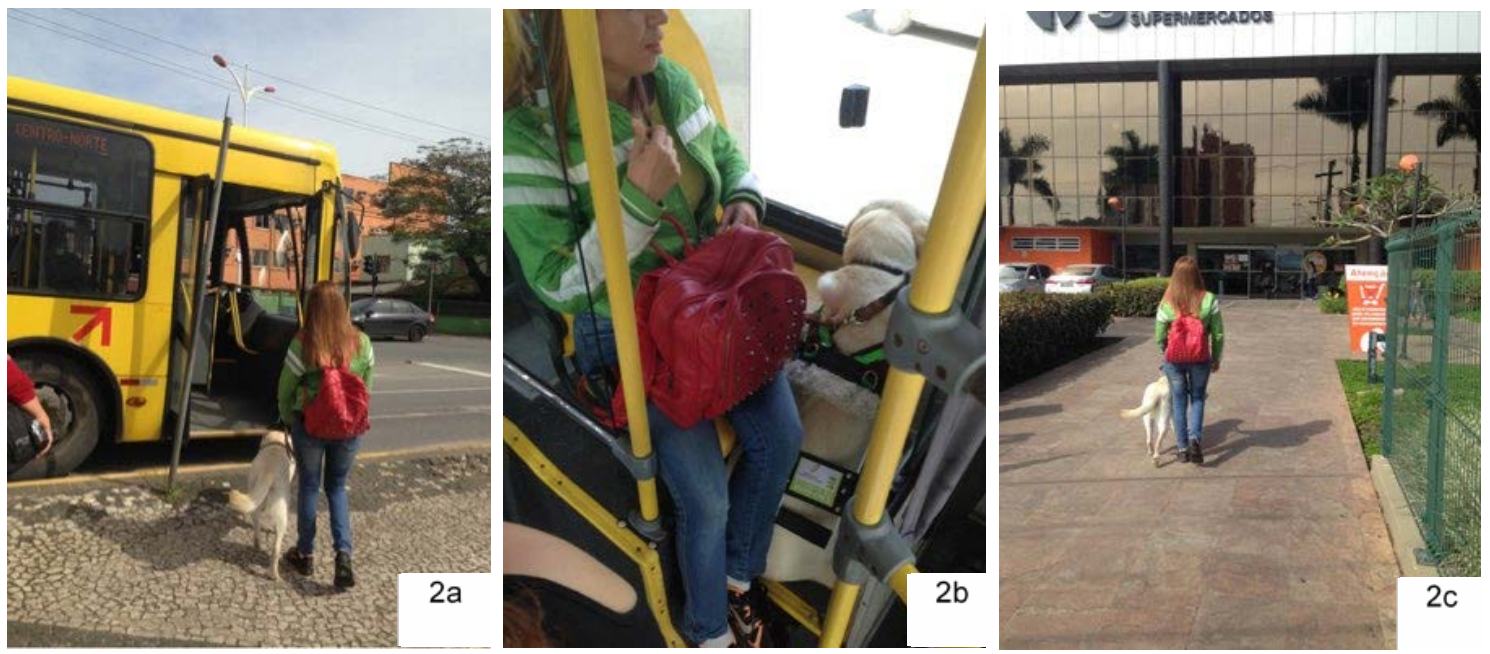

Source: Researcher's Photographic Collection (2015). 
Immediately after finishing, she bonces to the same bus stop she had previously disembarked and asked the researcher to sign when her bus is due to arrive. At the present, she was asked how she manages to call the right bus. She replies saying she has to sign all buses and ask the driver which route they are driving.

After boarding the vehicle (Figure 3a), she stops at the next bus station where she needs change routes. To move from the debarking point to the next route's embarking point, she was helped by a station staff (Figure 3b). Then, as she boards the next bus she immediately instructs the driver to stop at the ' $X$ ' street bus stop in front of the ' $Y$ ' reference point. After arriving at the instructed bus stop, she quickly walks with no obstacles in her way to home.

To conclude, is noticeable the importance of a guide dog as helps her to socialise - as seen while she was shopping - and to walk quickly. On evident obstacle was vehicles with high floors, which reduce even more her mobility as well of the elderly. Moreover, the absence of sound communication system inside the bus and in bus stops bar her ability to move independently, requiring someone's help constantly.

\section{São Paulo}

The second Accompanied walk occurred in São Paulo, in which the underground network was analysed based usability and accessibility. São Paulo (SP) is the most populous Brazilian city, with more than 12 million residents (INSTITUTO..., 2018), and is considered the 14th most globalised city on the planet. The underground network is the largest and busiest underground transportation system in Brazil, with having 78.4 kilometres of rail distributed in 6 six lines and a total of 67 stations. Audible information is offered in stations and on trains. Additionally, tactile floors and visual information are as well provided.

The accompanied interviewee is a 40-years-old blind woman (congenital blindness), cane user, graduated education and a language teacher. Her aim in this walk was to reach the São Paulo Art Museum (MASP) on Paulista Avenue using the underground network. Before any walk description, is imperative to highlight that the Paulista Avenue is the most important, busy and known street in São Paulo. It is widely accessible and with large sidewalks. In addition, the interviewee knows well the street but not the stations locations, making the route new to her.

The tour started at Vila Madalena underground station. She accessed the station by the preferential ratchet and using the tactile floors (Figure 4a). After accessing the station, the participant followed the tactile floor's indications to the alert tactile floor, having two directions to choose, one to the right and one to the left. Without knowing the correct way, the participant chose the wrong direction to his embarking point (Figures 4b and 4c).

Once she realised and she was moving in the opposite direction. She noticed the directing tactile floors were leading to an obstructed path to the lift rather than the platform stairs. As she continues moving to the obstructed footpath, the researcher guide her to the platform access and informed her that are some steps in the way. At this point, the participant asked to be escort across.

Figure 3 - The interviewee continues her route change the bus line to get her home
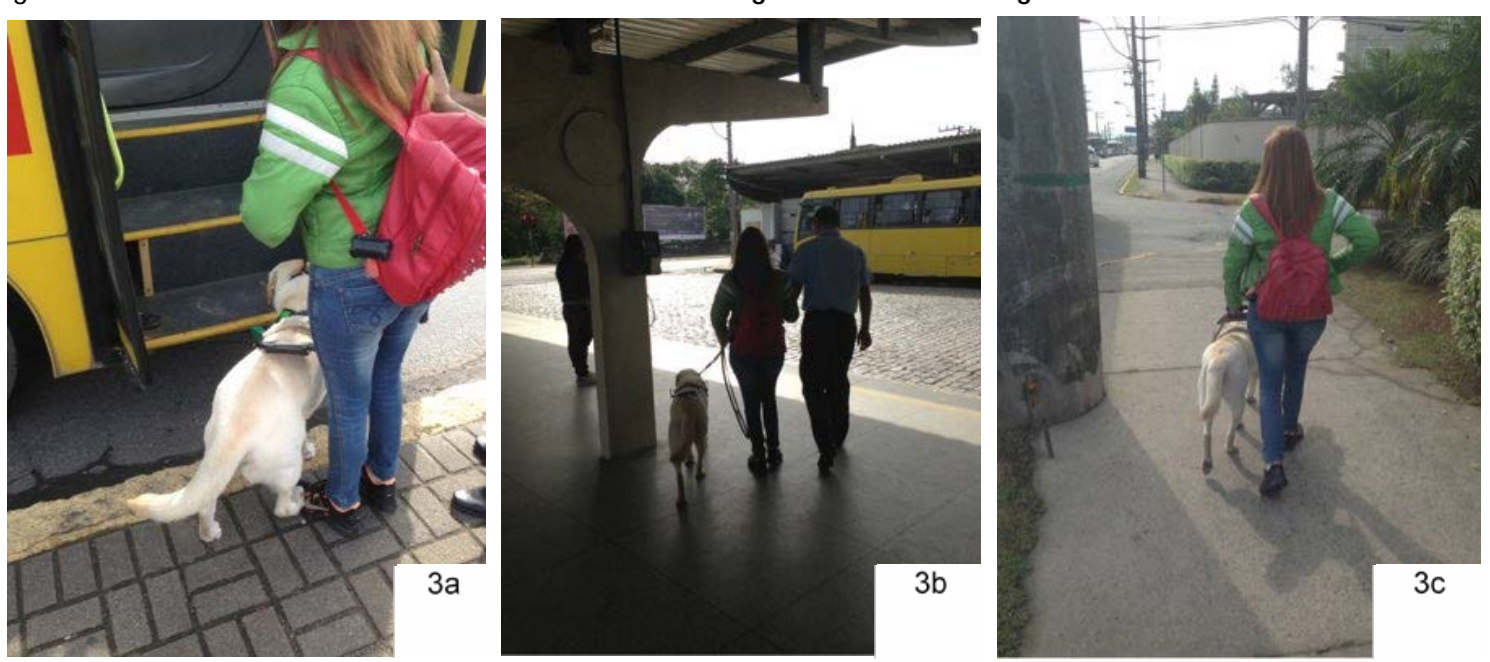

Source: Researcher's Photographic Collection (2015). 
Figure 4 - (a) Access to the subway station; and (b) and (c) tactile track directions
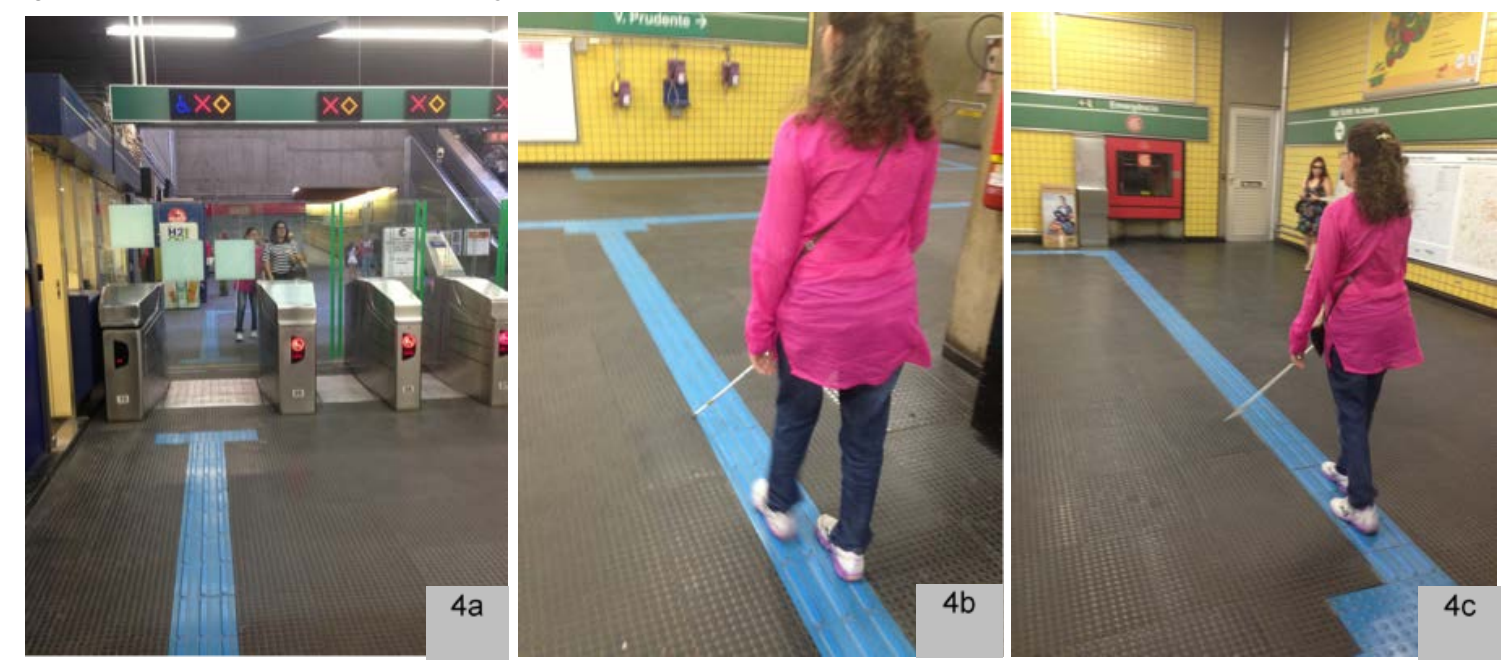

Source: Researcher's Photographic Collection (2015).

Going down to the platform, the participant had no problem with the stairs as alert tactile floors were installed both in the beginning and the end of the stair. Nevertheless, the corridor leading to the platform had no directional perceptible floors. She had only the flow of people and her surroundings perceptions to navigate with some clarity. On the other hand, the platform had directional tangible floor directing her to the edge of the platform where she waited for the train arrive (Figure 5b).

Immediately after the carriage arrived, the participant asked the research to safely help her to enter. After that, she quickly identified the preferred seats, which were located next to the doors (Figure 5c).

It is relevant to point out that neither in the station and in the vehicle sound information was available, at best, closing doors warnings. Conversely, the participant reported that most of the lines she habitually uses have sound information notifying the next stop, which was witnessed by the researcher on other occasions.

Due to the previous knowledge of the participant of the existing stations in this line, the moment of the disembark was detected by the number of previous stops, that besides the movement of vehicle parade, doors opening and the passenger movement.

On the opposite of the platform she in which she embarked, the disembarking platform had no guiding floors, only at some point of the following corridor (Figure 6b). At the present, she requested assistance.

Near to the station's exit, tactile floors were installed (Figure 6b), pointing to the exit. Yet, on the directional flooring junctions she was not clear which path should she take (Figure 6c), and once again the requested aid to the researcher.

After exiting and arriving at Paulista Avenue, the participant intuited the solar brightness of the afternoon. She noticed the pedestrian crossing by the guide floors and the movement of the cars. Subsequently, the participant stopped on the warning tactile floor, looking up with her cane the extension of the directional floor, which only started at the end of the ramp (Figure 7a). After identifying it, the participant follows it and arrives at the alert floor, indicating a change of direction (Figure 7b). Though, as the directional tread follows the road alignment, the participant had doubts which way to go.

When requested, she is guided by the researcher and follows the tactile floor towards the MASP. With little speed, the participant was capable of recognise the direction's change. It is noticed that the change of direction in $90^{\circ}$ can cause slowness since the user must grope other sides to make sure that it is a unique sole change of direction and no more options are presented (Figure 7c).

Next, the participant continues her journey as she flows the physical signs. Immediately after spotting the participant other pedestrians wake their way to her. As some sellers and exhibitors work on the pathway, very close to the tactile floor, the researcher alerts her and guided her sometimes.

Following her way, the participant confronted a new change of direction alert, which would lead her to a pedestrian crossing. But as she was instructed that the MASP was ahead, she continue her path. Not too long after, she faced over a new possible change of direction, which in this case was a newsstand in her way, forcing her to adjust her 
journey (Figure 8a). However, the floor had two options of direction: to follow the alignment of the walk or to the access of a building, leaving her in doubt (Figure 8b).

Arriving at another intersection, the interviewee easily identified as a potential pedestrian crossing (Figure 9a), by the referential ramp inclination. At the next corner, in which MASP was located, no tactile floor was available, imposing the participant to bypass the building alignment seeking access to the Museum (Figure 9b). However, at this alignment some bicycles were parked, making it impossible for the participant to follow through (Figure 9c). Complementarily, without tactile floor the crowd did not allow safe displacement, so the participant was guided by the researcher to the access of the Museum, ending the journey.

Figure 5 - (a) Tactile floor signals in the stairs; b- guide floor on the platform; and (c) finding the preferred seat
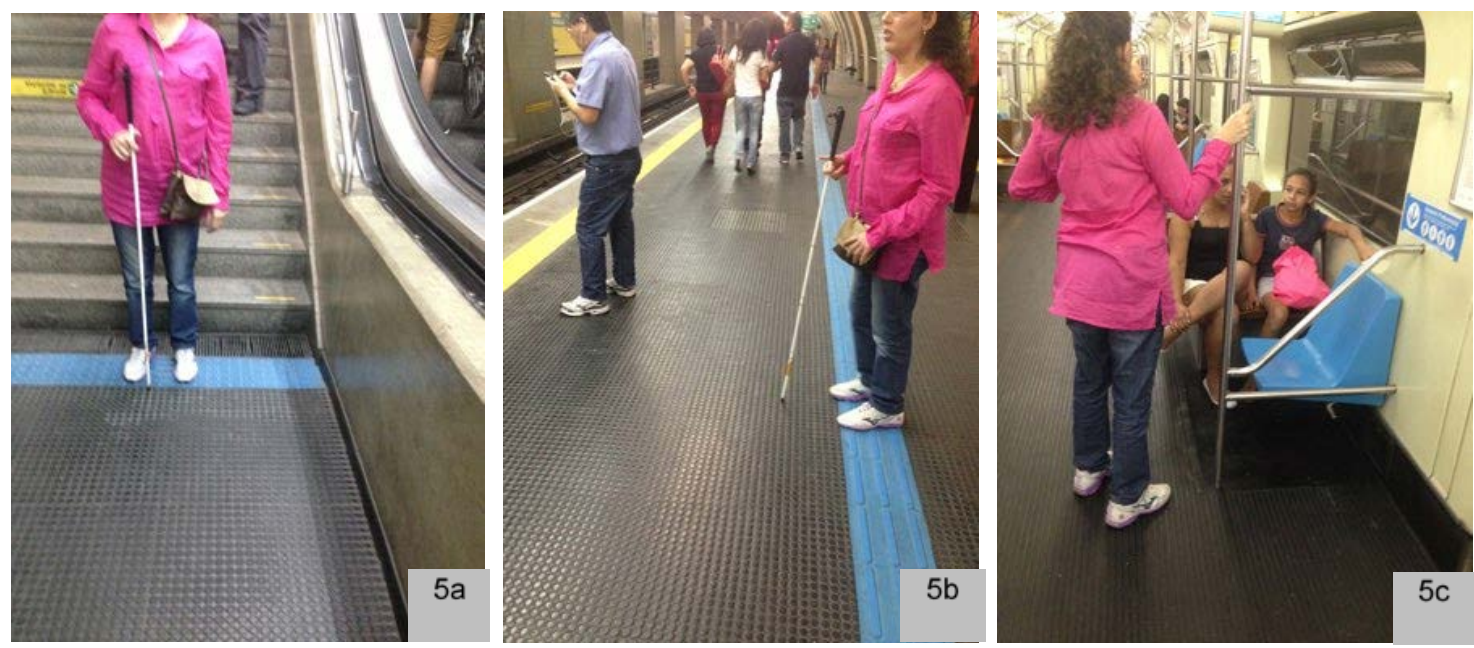

Source: Researcher's Photographic Collection (2015).

Figure 6 - (a) Disembarking; (b), (c) and (d) changing the directions; and (e) going out of the station
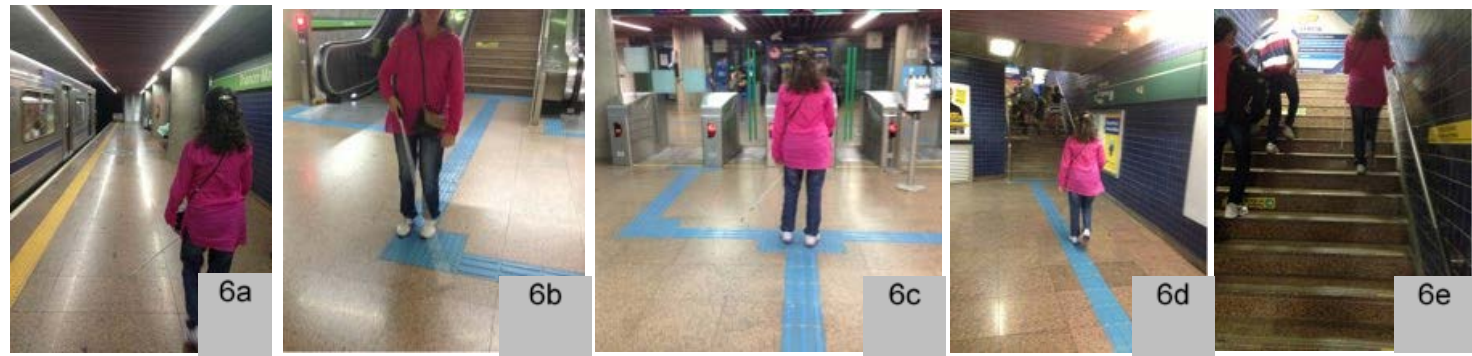

Source: Researcher's Photographic Collection (2015).

Figure 7 - (a) After crossing; (b) tactile floor directs to the wall and causes confusion in understanding; and $(c)$ turning the corner using the tactile floor in 90 은
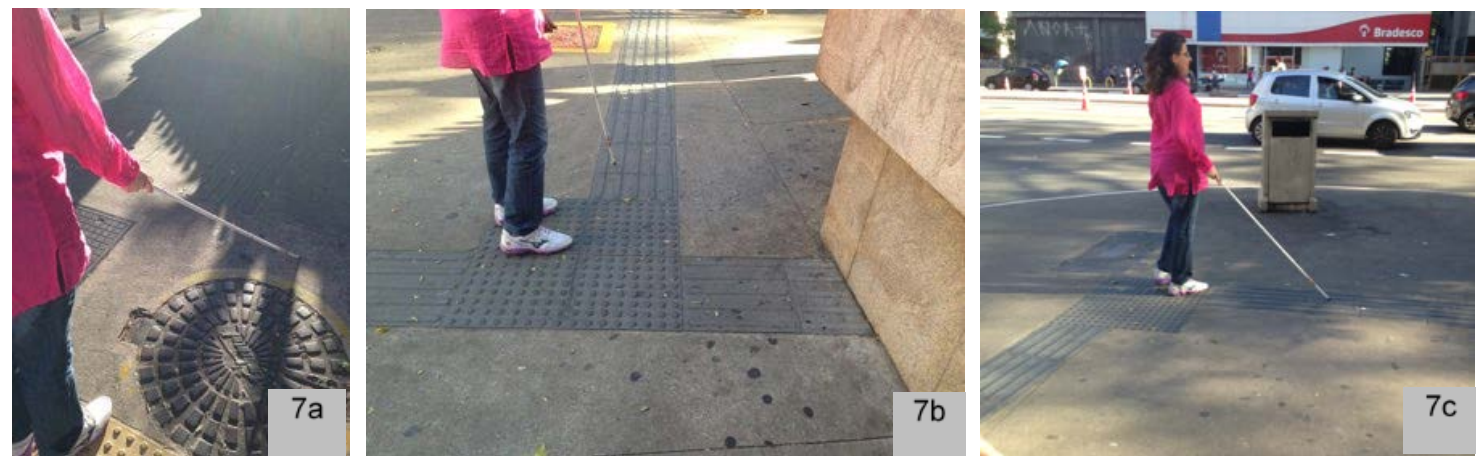

Source: Researcher's Photographic Collection (2015). 
Figure 8 - (a) The presence of the newsstand; (b) deviation of the guide floor; and (c) finding the linear path to follow
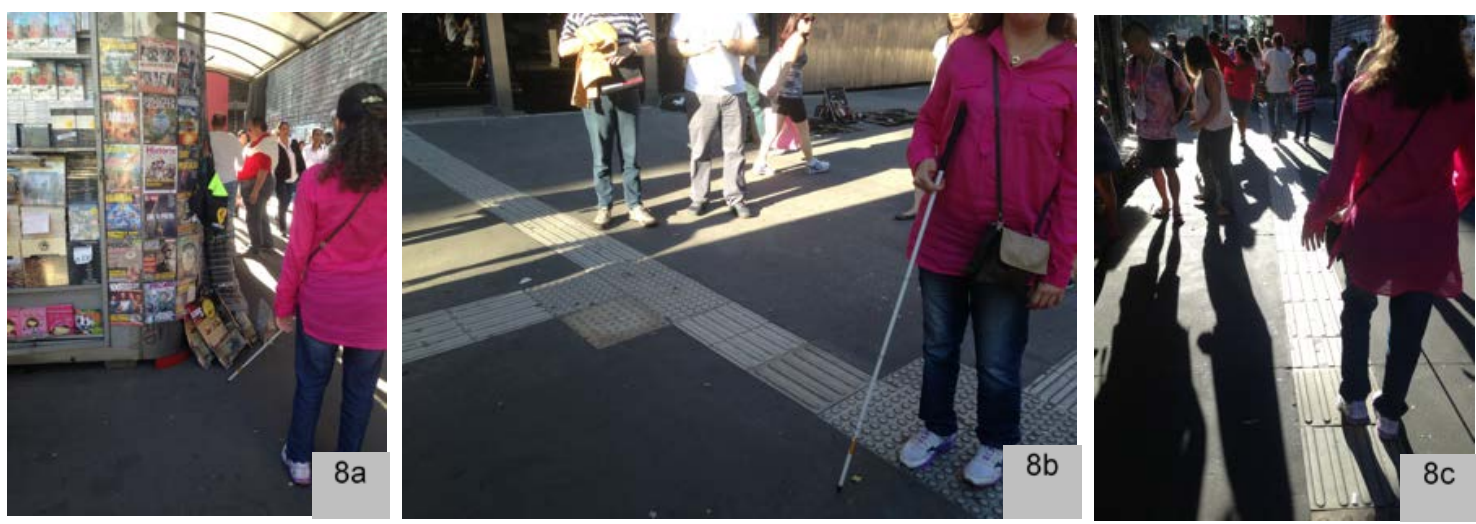

Source: Researcher's Photographic Collection (2015).

Figure 9 - (a) Identifying pedestrian crossing; and (b) and (c) finding the MASP
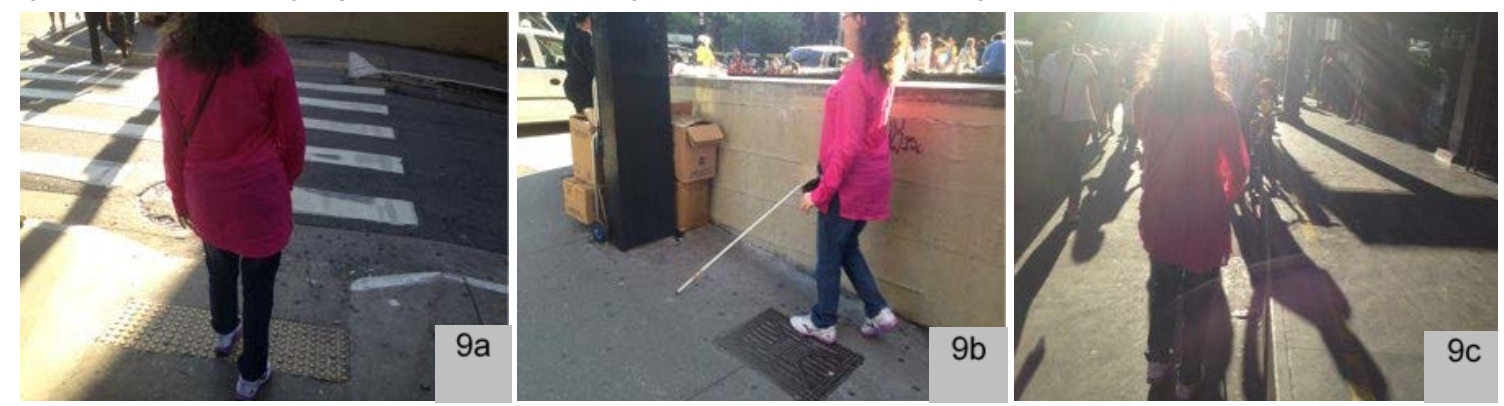

Source: Researcher's Photographic Collection (2015).

After the tour, the interviewee stated that it was easier to identify the tactile floor in underground station than on sidewalks of Paulista Avenue, claiming that the thickness of the tactile is greater.

\section{Florianópolis}

Lastly, the third 'Accompanied Walk' was in Florianópolis, the capital of Santa Catarina State, two hours' drive from Joinville. The municipality is formed by an island and the main land and hosting a population of 492,977 inhabitants (INSTITUTO..., 2018). Its public transport network has 454 buses running through nine stations and at the time there was no information system available.

In this walk the researcher followed a 46-years-old graduated blind man and cane user who works as an administrative officer in an education centre. The journey took place in the city centre and had the central bus station as an origin point. Straight to the point, the participant reported a series of details about his abilities in his displacement (Figure 10):

(a) he is able to sense the presence of buses through the air vibrations, and he can detect passengers embarking and disembarking; (b) through the different air atmospheres and movements of sound he has the ability to detect the exact doors' position, with the support of his cane; and

(c) as soon he notices the presence of others in his way, he normally slows down to avoid any confrontations.

Additionally, he comments about the personal injury that tactile floors can cause. Explain that to understand when is a tactile floor alert and when is directional have to leave the foot diagonally, to feel the difference in relief. It emphasizes the importance of the material of the adjacent floor, not causing confusion, as found in the public market and in central sidewalks (Figure 11), in which the interviewee cannot distinguish the floor.

During the tour of the central area and public market, the interviewee explain that he perceives the spatial configuration by the subtle changes in sound reverberation, for example: when the sound returns quickly the walls are close and the place is small; when the sound is slow to return or causes echo, the walls are distant, and the place is wide. In addition, he explained how he 'read the traffic', understanding the movement and direction in which vehicles are heading, the dynamics of the place and 
the people's movement. Figure 12 shows as an example a crossing, where he perceived the change of the movement of the air. He managed to identify the pedestrian's crossing by the different flooring, by the sound emitted by the pedestrian traffic light and people's movement around him.

At this point, the interviewee points out the lack of criteria in using tactile floors, stressing several confusing applications, which makes this tool unreliable, such as different situations showed in Figure 13.
To conclude, although the participant had finished the walk at the Central Bus Station, it was possible to argue that without accessible information availability in the public transport network, which includes the commute from the residence/work to the bus stop, he only depended on himself, not precisely knowing if he would be able to finish his trip. However, this particular interviewee is highly reliable on his other senses, perceiving the natural light, wind ambience, surrounding movements and sounds in order to guide him through his journey.

Figure 10 - On the left, tactile floor alert with columns of relieves aligned, reported as confused and similar to the relief of directional floor; to the center and to the right, tactile floor alert with misaligned columns, reported as more easily detected
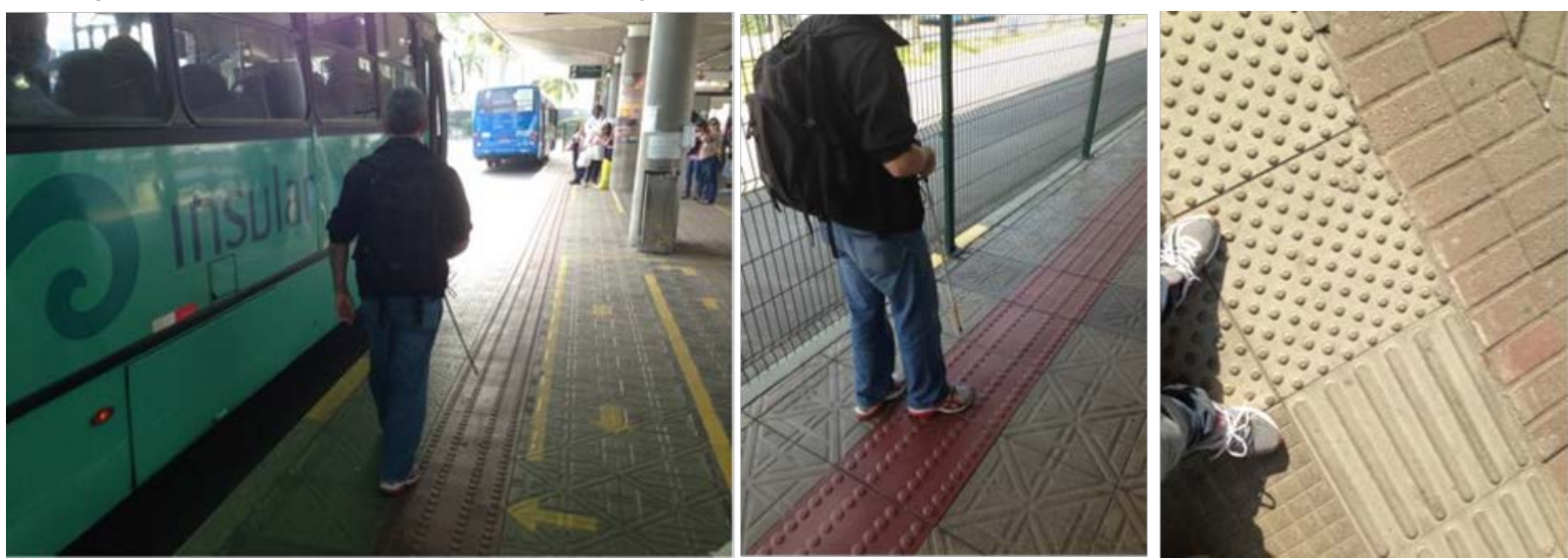

Source: Researcher's Photographic Collection (2015).

Figure 11 - Roughness of the adjacent floor causes confusion
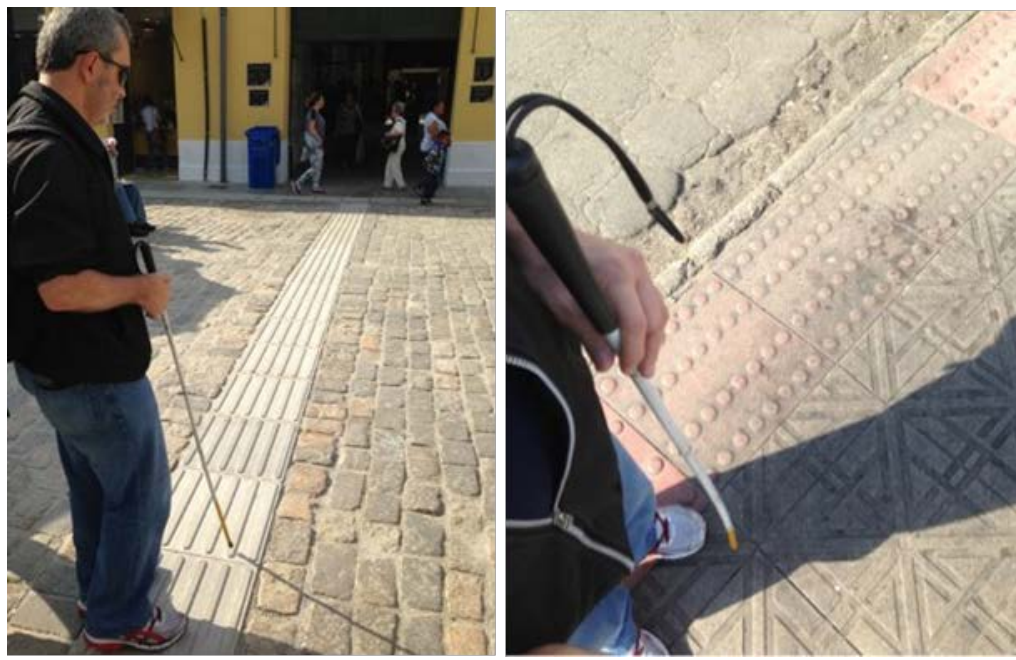

Source: Researcher's Photographic Collection (2015). 
Figure 12 - Perception of pedestrian crossings
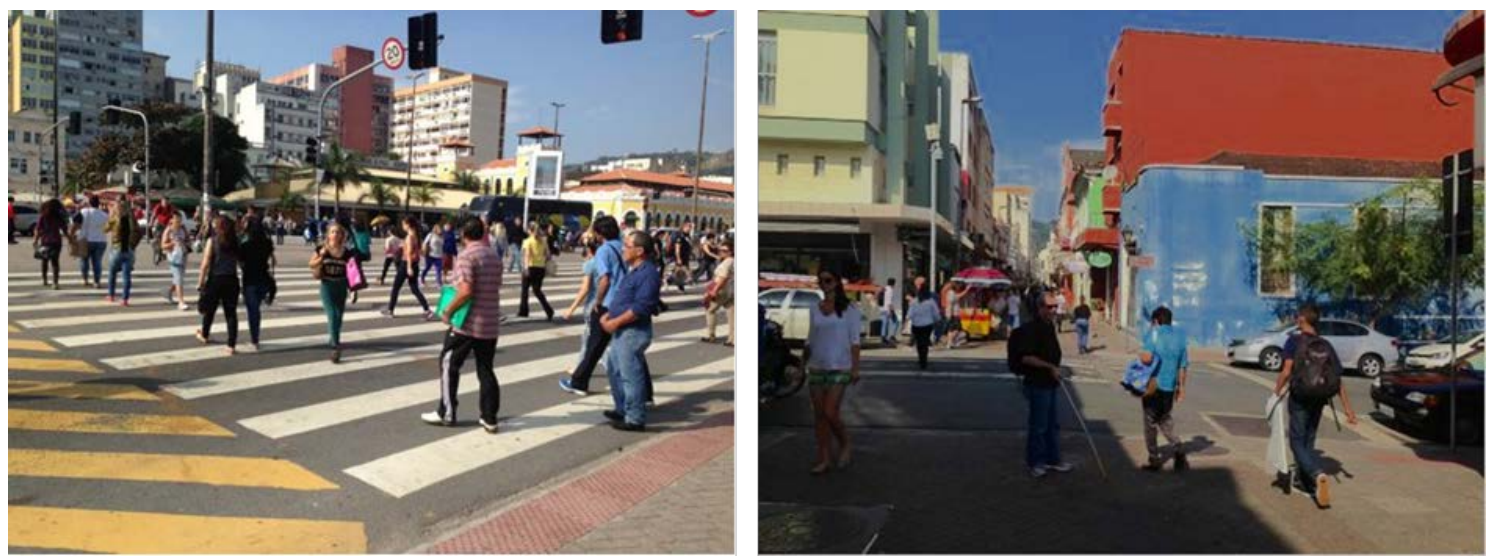

Source: Researcher's Photographic Collection (2015).

Figure 13 - Tactile floor applied wrongly
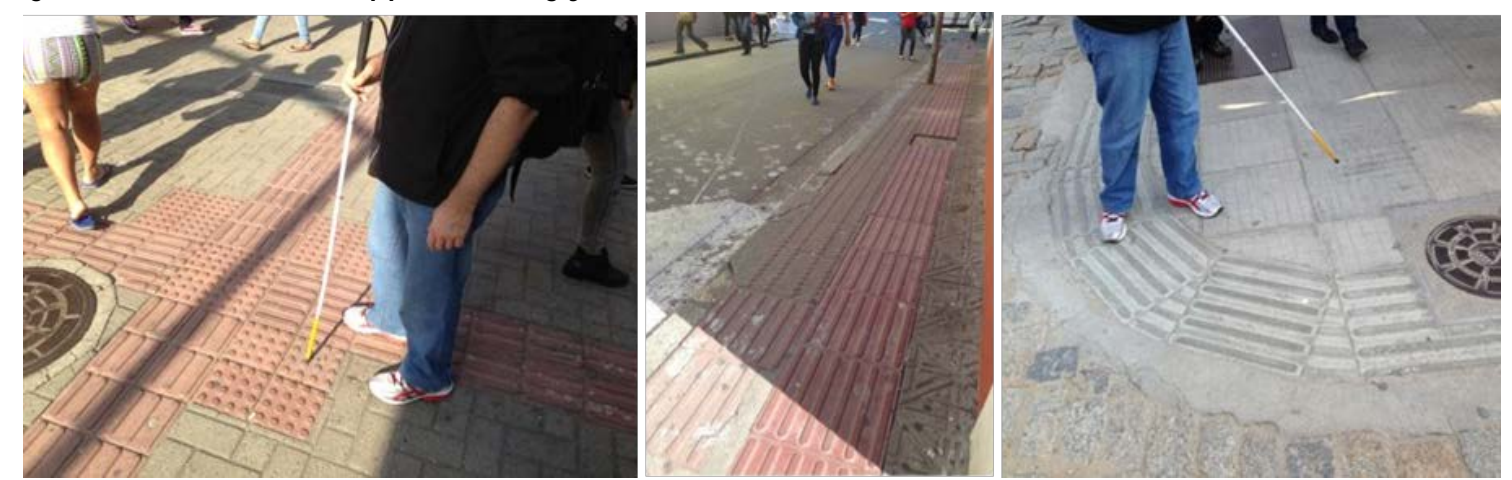

Source: Researcher's Photographic Collection (2015).

\section{Non-visual senses and references for orientation and mobility identified in the accompanied walks}

Supported by the results from the 'Accompanied Walks' and the supplement applied methods, it was possible to identify the main references used for orientation and movement of people with blindness or low vision, from the embark to disembark of the vehicles, walking to a public transport access point - inside or outside stations as well. The spatial references, their sensory channels, stimulus obtained and their potential meaning outcomes are presented in Table 2. For the table structuring, the Gibson' (1966) sensory perception system was referenced, followed the organization and specifications of the table of Dischinger (2000)' "Sources of non-visual information".

Thus, the table was designed to show each particular step of the 'Accompanied Walk': walking; embarking and supplementary movement (when elements such as the unevenness of sidewalks as reference to cross a street, in which a sonic or palpable traffic light should be available to complete the primary action autonomously); and embarking only.

The first line, for example, is to detect a crosswalk, which is perceive through orienting system and the haptic, the stimulus obtained was the inclination of the feet and correction for the body balance axis, because of the slope and ramp, signifying a safe place to cross the street.

\section{Conclusions}

'Accompanied Walks' was a powerful tool of understating the importance of fully accessible information systems. However, the Brazilian public transport network is far from ideal, and from the cities studied only São Paulo shows some degree of adequate communication to visually impaired commuters. 


\section{Table 2 - The non visual senses and the urban references during walking and embarked}

\begin{tabular}{|c|c|c|c|c|c|}
\hline & References & $\begin{array}{l}\text { Perceptual } \\
\text { Channel }\end{array}$ & Stimulus Obtained & Resultant Information & Potential Meaning \\
\hline \multirow{4}{*}{$\begin{array}{l}\text { W } \\
\mathbf{A} \\
\mathbf{L} \\
\mathbf{K} \\
\mathbf{I} \\
\mathbf{N} \\
\mathbf{G}\end{array}$} & $\begin{array}{l}\text { sidewalk's slope } \\
\text { and ramp }\end{array}$ & $\begin{array}{l}\text { Orienting and } \\
\text { Haptic System }\end{array}$ & $\begin{array}{l}\text { inclination of the feet } \\
\text { and correction for the } \\
\text { body balance axis }\end{array}$ & crossing of pedestrians & safe place to cross a street \\
\hline & $\begin{array}{l}\text { different textures } \\
\text { (tactile floors, } \\
\text { type of paving) }\end{array}$ & $\begin{array}{l}\text { Haptic and } \\
\text { Auditory } \\
\text { System }\end{array}$ & $\begin{array}{l}\text { different sounds } \\
\text { produced by the flare of } \\
\text { the cane. Feet feel } \\
\text { different textures }\end{array}$ & $\begin{array}{l}\text { delimitation of street and } \\
\text { sidewalks. Information } \\
\text { about tactile floors (change } \\
\text { of direction, move on, } \\
\text { obstacle, etc.) }\end{array}$ & $\begin{array}{l}\text { possible or safe way forward / } \\
\text { inappropriate walking places }\end{array}$ \\
\hline & own movement & $\begin{array}{l}\text { Orienting and } \\
\text { Haptic System } \\
\text { Perception of } \\
\text { Time }\end{array}$ & $\begin{array}{l}\text { Forces of gravity and } \\
\text { acceleration, tissue } \\
\text { deformation, joint } \\
\text { configurations; } \\
\text { instantaneous and } \\
\text { sequential events }\end{array}$ & $\begin{array}{l}\text { Body balance; direction and } \\
\text { (de) acceleration of motion; } \\
\text { body positions; duration } \\
\text { and rhythm }\end{array}$ & $\begin{array}{l}\text { Relative position in space; speed } \\
\text { and pace of movement; direction } \\
\text { and distance; notion of movement } \\
\text { and actions, notion of sequence; } \\
\text { pace and duration of movement }\end{array}$ \\
\hline & $\begin{array}{l}\text { platforms in } \\
\text { stations }\end{array}$ & $\begin{array}{l}\text { Orienting and } \\
\text { Haptic System }\end{array}$ & $\begin{array}{l}\text { touch of the cane with } \\
\text { pedestrian platforms } \\
\text { unevenness and rolling } \\
\text { range of vehicles }\end{array}$ & $\begin{array}{l}\text { linear direction, } \\
\text { delimitation of spaces }\end{array}$ & $\begin{array}{l}\text { safe place to follow continuously } \\
\text { until the place of embarkation or } \\
\text { departure from the station }\end{array}$ \\
\hline \multirow{6}{*}{$\begin{array}{c}\mathbf{W} \\
\mathbf{A} \\
\mathbf{L} \\
\mathbf{K} \\
\mathbf{I} \\
\mathbf{N} \\
\mathbf{G} \\
\\
\mathbf{A} \\
\mathbf{N} \\
\mathbf{D}\end{array}$} & different sounds & $\begin{array}{l}\text { Auditory } \\
\text { System }\end{array}$ & Air Vibration & $\begin{array}{l}\text { Nature and location of the } \\
\text { sound source (station, } \\
\text { crossing, restaurant, school, } \\
\text { square, etc.) }\end{array}$ & $\begin{array}{l}\text { recognition and location of nearby } \\
\text { and distant activities; dimensions } \\
\text { of the environments; location of } \\
\text { walls and openings, information } \\
\text { emitted by sound systems / } \\
\text { applications / presence of vehicles } \\
\text { / arrivals and departures, etc. }\end{array}$ \\
\hline & different smells & $\begin{array}{l}\text { Taste / smell } \\
\text { System }\end{array}$ & Chemicals in the air & $\begin{array}{l}\text { Nature and location of } \\
\text { activities and spaces (fuel } \\
\text { station, bakery, pharmacy, } \\
\text { shoe store, etc.) }\end{array}$ & $\begin{array}{l}\text { confirm the location of a place or } \\
\text { identify activities (smell of fuel } \\
\text { when entering the station or on a } \\
\text { motorized street) }\end{array}$ \\
\hline & wind & $\begin{array}{l}\text { Haptic and } \\
\text { Auditory } \\
\text { system }\end{array}$ & $\begin{array}{l}\text { Different pressures and } \\
\text { temperature felt by the } \\
\text { skin; Vibration and } \\
\text { sound of the air }\end{array}$ & $\begin{array}{l}\text { Directions, intensity and } \\
\text { temperature of the wind, } \\
\text { sound of the wind }\end{array}$ & $\begin{array}{l}\text { Vehicle openings (windows and } \\
\text { doors), perception of corners; } \\
\text { places that are known to receive } \\
\text { wind }\end{array}$ \\
\hline & sun and shadow & Haptic system & $\begin{array}{l}\text { temperature felt by the } \\
\text { skin; perception of } \\
\text { clarity and darkness (for } \\
\text { people who can still } \\
\text { distinguish light) }\end{array}$ & $\begin{array}{l}\text { Different temperatures, } \\
\text { light and dark }\end{array}$ & $\begin{array}{l}\text { The sides of the street, the } \\
\text { presence of vegetation, buildings } \\
\text { and vertical / horizontal surfaces } \\
\text { (such as entering a station - by the } \\
\text { cover); geographical orientation; } \\
\text { notion of time }\end{array}$ \\
\hline & $\begin{array}{l}\text { surfaces of } \\
\text { support } \\
\text { (dimensions, } \\
\text { shapes, levels, } \\
\text { texture) }\end{array}$ & $\begin{array}{l}\text { Orienting and } \\
\text { Haptic System }\end{array}$ & $\begin{array}{l}\text { Deformation of the } \\
\text { tissues, configuration of } \\
\text { joints, forces of gravity }\end{array}$ & $\begin{array}{l}\text { contact with different } \\
\text { materials; shapes of objects; } \\
\text { material state (strength / } \\
\text { viscosity) }\end{array}$ & $\begin{array}{l}\text { safe places to walk; preferential } \\
\text { seats; tactile track }\end{array}$ \\
\hline & motor vehicles & $\begin{array}{l}\text { Auditory and } \\
\text { Haptic System }\end{array}$ & $\begin{array}{l}\text { Vibration and sound } \\
\text { output }\end{array}$ & Number of vehicles & $\begin{array}{l}\text { location of stations, the street, } \\
\text { parking lots, fuel stations }\end{array}$ \\
\hline \multirow{2}{*}{$\begin{array}{c}\mathbf{E} \\
\mathbf{M} \\
\mathbf{B} \\
\mathbf{A} \\
\mathbf{R} \\
\mathbf{K} \\
\mathbf{E} \\
\mathbf{D}\end{array}$} & $\begin{array}{l}\text { vehicle } \\
\text { movement }\end{array}$ & $\begin{array}{l}\text { Orienting and } \\
\text { Haptic System } \\
\text { Perception of } \\
\text { Time }\end{array}$ & $\begin{array}{l}\text { acceleration, braking, } \\
\text { right, left, up and down }\end{array}$ & $\begin{array}{l}\text { curves, conversions, spines, } \\
\text { traffic flow, number of } \\
\text { vehicles, traffic lights, } \\
\text { crosswalk }\end{array}$ & $\begin{array}{l}\text { location of stations, the street, } \\
\text { parking lots, fuel stations. } \\
\text { location of the vehicle, proximity } \\
\text { to reference points (may be } \\
\text { revealed by number of spines or } \\
\text { conversions, for example) }\end{array}$ \\
\hline & $\begin{array}{l}\text { vehicle access / } \\
\text { exit door / } \\
\text { preferred seat }\end{array}$ & $\begin{array}{l}\text { Orienting, } \\
\text { Auditory and } \\
\text { Haptic System }\end{array}$ & $\begin{array}{l}\text { sound shadow, air } \\
\text { movement, ratchet } \\
\text { sound, driver's speech } \\
\text { and movements }\end{array}$ & $\begin{array}{l}\text { perception of the driver's } \\
\text { location, ratchet, vehicle } \\
\text { entry and exit }\end{array}$ & place to go, sit and go \\
\hline
\end{tabular}

Source: Silveira (2017). 
In general, the interviewees used all their remaining senses to recognise the environments where they had already made trips. The walks have shown the importance of tactile floors along public transport routes and in stations deliver the self-sufficiently movement needed by those with blindness or low vision. Besides, tactile floors in transport access point and on sidewalks was named vital to prevent dangerous situations. Nevertheless, such independency is scraped when further essential information is absent, such as tactile maps, sound announcement, or badly design tactile guiding floors. For many of those participants in any of the methods applied on this research, the lack of reachable information not only restrict their daily movement around the city but also in an event of changes in stations or routes, or the adding of new services makes their journey nearly impossible. As their ability of using other senses is useless if they do not know where they have to be. They had to employ strategies to know where they were located and when they should be disembarked, such as storing numbers of turns and stops.

Another situation encountered by these particular travellers is crowding in access point, which can have two opposing strands: it might limit their walking as they will either be using a cane or being guided by a dog; on the other hand, numerous passengers on foot to the same point of access can direct them to their access/exit points.

In total, eight main observations are made after concluding the research:

(a) the lack or non-existence of accessible information about the transport network;

(b) the numerous obstacles during the walks;

(c) the privation of tactile floors continuity and its incorrect design, then when applied correctly provides a safe route, offering confidence by its users;

(d) the understanding of the theory applied in practice: how visually impaired people custom their other senses to perceive the space;

(e) how partially sighted people uses their residual vision and those with blindness with light perception uses this sense to be able to selforiented in urban spaces;

(f) how guiding dogs as are socialising agent and facilitator in urban displacements, providing greater security and safety of to the person with blindness;

(g) in the total absence of information, blind people use all their available perception systems to orientate themselves; and (h) even when existing visual information the blind needs to ask and depends on who can see.

Moreover, the 'Accompanied Walks allowed to obtain a new perspective about the self-orientation and mobility, and the strategies and references that the people with visual impairment use to navigate in urban public transport networks. It was noticed the relevance of attitudinal accessibility regarding the assistive technology usage as an effective supplementary tool to self-reliantly movement. In contrast, when mobile obstacles were placed on the pavement the blind became lost as the tactile floor was interrupted and no indication - for they - is normally available.

Finally, it is comprehended the basic elements to offer a good and accessible information system are: sound communication in the stations and inside the vehicles; the existence of tactile floors to indicate the routes and to direct to perceptive maps about the spatial configuration of stations; main information in Braille when there are visual signs; accessible applications for smartphones informing the lines, routes and frequency so the visually impaired person can use the same information system through a mobile screen reader. To summarised, the providence of accessible information systems are essential for any user to be able to cognise the transportation network and the urban spaces around, and be capable to reach his/her desired destination independently.

\section{References}

BELL, P. A. et al. Environmental Psychology. Philadelphia: W. B. Saunders Company, 1978.

BRASIL. Lei Federal 12.587/2012, que institui a Política Nacional de Mobilidade Urbana. Diário Oficial da União, 2012.

DISCHINGER, M. Designing For All Senses: accessible spaces for visually impaired citizens. Göteborg, 2000. 260 f. Thesis (Doctor of Philosophy) - Department of Space and Process School of Architecture, Chalmers University of Technology, Göteborg, 2000.

\section{GIBSON, J. J. The Senses Considered as}

Perceptual Systems. Boston: Houghton Mifflin. 1966.

\section{HERSSENS, J. Designing Architecture for}

More: a framework of haptic design parameters with the experience of people born blind. PHL University College-University Hasselt, K.U.Leuven, Flanders. Heverlee, 2011. 
INSTITUTO BRASILEIRO DE GEOGRAFIA E ESTATÍSTICA. População Estimada 2018.

Disponível em: <http://www.ibge.gov.br>. Acesso em: 01 out. 2018.

\section{OKAMOTO, J. Percepção Ambiental e}

Comportamento: visão hotística da percepção ambieníal na arquitetura e na comunicação. São Paulo: Ed. Mackenzie, 2002.

SILVEIRA, C. S. Orientação e Mobilidade de Pessoas com Deficiência Visual no Meio Urbano e no Transporte Coletivo: subsídios para sistemas de informação ao usuário. Florianópolis, 2017. 356 f. Thesis (Doctorate in Architecture and Urbanism) - Post-Graduate Program, Universidade Federal de Santa Catarina, Florianópolis, 2017.

\section{Acknowledgments}

The researcher thanks all the participants, especially the interviewees who participate in the

Accompanied Walk method.

The thesis was conducted during a scholarship supported by CAPES - Brazilian Federal Agency for Support and Evaluation of Graduate Education within the Ministry of Education of Brazil.

\section{Carolina Stolf Silveira}

Doutora pelo Programa de Pós Graduação em Arquitetura e Urbanismo | Universidade Federal de Santa Catarina | Rua Anita Garibaldi, 770 | J oinville - SC - Brasil | CEP 89203-300 | Tel.: (47) 99133-0478 | E-mail: carolinastolf@gmail.com

\section{Marta Dischinger}

Departamento de Arquitetura e Urbanismo | Universidade Federal de Santa Catarina | Florianópolis - SC - Brasil | Caixa Postal $10060 \mid$ CEP 88062-970 | Tel.: (48) 3721-9550 | Tel Cel: 48 99229465 | E-mail: martadischinger@gmail.com

\section{Revista Ambiente Construído}

Associação Nacional de Tecnologia do Ambiente Construído

Av. Osvaldo Aranha, 99 - 3o andar, Centro

Porto Alegre - RS - Brasil

CEP 90035-190

Telefone: +55 (51) 3308-4084

Fax: +55 (51) 3308-4054

www. seer. ufrgs. br/ ambienteconstruido

E-mail: ambienteconstruido@ufrgs.br 